DOI: 10.34015/2523-4552.2019.3.19

Удк 343.85

Богатирьова О. I.,

доктор юридичних наук, старший

науковий співробітник, професор кафедри

кримінального права та кримінології

Університету державної фіскальної

служби України

ORCID ID: 0000-0003-4630-4408

Михайлик О. Г.,

кандидат юридичних наук, докторант

кафедри управління безпеки,

правоохоронної та антикорупційної

діяльності Вищого навчального закладу

«Міжрегіональна Академія управління

персоналом»

e-mail: dmitriyyy92@ukr.net

ORCID ID: 0000-0002-2113-4888

\title{
ВЗАЄМОЗВ'ЯЗОК КРИМІНАЛЬНОЇ СУБКУЛЬТУРИ ТА НАСИЛЬСТВА В МІСЦЯХ НЕСВОБОДИ
}

У статті розкрито взаємозв'язок кримінальної субкультури та насильства в місцях несвободи. Наведено погляди вітчизняних і зарубіжних вчених на поняття кримінальна субкультура в місцях несвободи. 3'ясовано залежність рівня і структури насильства в місцях позбавлення волі від наявної кримінальної субкультури серед засуджених. Доведено, що кримінальна субкультура має власну кримінальну ідеологію серед засуджених. Виокремлено основні ознаки взаємозв'язку кримінальної субкультури та насильства в місцях несвободи.

Ключові слова: кримінальна субкультура; насильство; засуджений; місия несвободи; злочинність.

В статье рассмотрена взаимосвязь криминальной субкультуры и насилия в местах несвободы. Приведены взгляды отечественных и зарубежных ученых на понятие криминальная субкультура в местах несвободы. Выяснена зависимость уровня и структуры насилия в местах лишения свободы и криминальной субкультуры среди осужденных. Доказано, что криминальная субкультура имеет собственную уголовную идеологию среди осужденных. Выделены основные признаки взаимосвязи криминальной субкультуры и насилия в местах несвободы.

Ключевые слова: криминальная субкультура; насилие; осужденный; места несвободы; преступность. 
Постановка проблеми. Актуальність дослідження обумовлена, в першу чергу, недосконалістю кримінально-виконавчого законодавства України, яке регулює порядок і умови виконання покарання у виді позбавлення волі; не належним контролем персоналу установ виконання покарань Міністерства юстиції України за засудженими, які підтримують злодійські традиції серед засуджених; відсутністю серед вітчизняних вчених єдиної думки щодо взаємозв'язку кримінальної субкультури та насильства в місцях несвободи тощо.

Вбачається, що взаємозв'язок кримінальної субкультури та насильства в місцях несвободи сприяє розвитку агресії, культу насильства та жорстокості серед засуджених, підвищує злочинний професіоналізм та інтенсивність криміналізації окремої групи засуджених перед іншими, формує живучість злочинних та тюремних традицій, згуртованість певної групи засуджених 3 метою протистояти адміністрації установи виконання покарань, не виконувати вимоги режиму та продовжувати злочинну діяльність.

Більше того, дослідження насильства в місцях несвободи зумовлена тим, що феномен насильства i вплив кримінальної субкультури на його вияв в місцях несвободи залишається майже не вивченим. У більшості випадків це аргументується тим, що досить довгий час така проблема була прихована для суспільства, а у звітах установ виконання покарань взагалі графа субкультура серед засуджених виключена.

Водночас варто зауважити, що кримінальна субкультура в місцях несвободи характеризується наступ- ними ознаками: специфічними умовами відбування кримінального покарання; істотною прихованістю від адміністрації виправної колонії; упорядкованістю життя співтовариств засуджених; єдиною сферою злочинної діяльності; живучістю та згуртованістю кримінальної активності; багатоступінчастою ієрархічною структурою тощо.

Крім того, кримінальна субкультура та насильство в місцях несвободи визначається своєю специфікою й унікальністю взаємозв'язаних чинників, притаманних саме цим місцям. I хоча кримінальна субкультура та насильство суперечить цінностям, які притаманні суспільству, на жаль, особа, яка засуджена за злочин і потрапляє під вплив такої субкультури або насильства, дозволяє позбавити себе тих соціальних заборон, якими вона керувалася до засудження.

Слід визнати, що сьогодні кримінальна субкультура та насильство в місцях несвободи $є$ впорядкованою системою взаємовідносин між засудженими, вмілим культивуванням негативних цінностей, звичаїв та традицій злочинного середовища. I тому зрозуміло, що кримінальні групи, які формуються в місцях несвободи і дотримуються певних законів та традицій, визнають свій спосіб життєдіяльності через призму або субкультури або насильства.

Однак, не слід забувати, що цим кримінальним групам властиві такі ознаки як агресія, розмитість моральних норм, манера поведінки, татуювання, жорстокість, насильство, відсутність заборон, статева розбещеність тощо.

Аналіз останніх досліджень i публікацій. Окремі аспекти взає- 
мозв'язку кримінальної субкультури та насильства в місцях несвободи досліджували у свої наукових працях багато науковців, серед яких А. I. Богатирьов, I. Г. Богатирьов, I. В. Боднар, В. Б. Василець, О. В. Ведмідський, Л. Ф. Гула, О. М. Гумін, Б. М. Головкін, О. М. Джужа, З.В. Журавська, О.Г. Колб, В.Я. Конопельський, I. М. Копотун, В. В. Лопух, С. Ю. Лукашевич, О. О. Некрасов, В. А. Носенко, В. Г. Павлов, М. С. Пузирьов, Е. Г. Стоматов, А. В. Ткаченко, В. В. Шаблистий, Л. Г. Якименко та ін.

Серед невирішених проблем взаємозв'язку кримінальної субкультури та насильства в місцях несвободи ми виділяємо: негативний вплив кримінальної субкультури та насильства на засуджених в установах виконання покарань; не проведення з боку адміністрації установи виконання покарань кримінологічного аналізу кримінальної субкультури та насильства в місцях несвободи, що не дає можливість оцінити інтенсивність криміногенного впливу їх; відсутність виділення основних ознак взаємозв'язку кримінальної субкультури та насильства в місцях несвободи тощо.

Постановка завдання. Метою статті $€$ розгляд взаємозв'язку кримінальної субкультури та насильства в місцях несвободи, що надасть змогу адміністрації установи виконання покарань своєчасно реагувати на дані явища серед засуджених у процесі відбування ними покарання.

Виклад основного матеріалу. Проведений нами аналіз наукових праць на предмет взаємозв'язку кримінальної субкультури та насильства в місцях несвободи показує, що більша частина кримінологів вважає, що їх взаємозв'язок в місцях несвободи ретельно приховується засудженими від адміністрації установ виконання покарань. За нашим дослідження, це не зовсім так.

На запитання оперативних працівників виправних колоній Міністерства юстиції України 86\% підтвердили нашу гіпотезу, що адміністрація виправних колоній, ще до прибуття засудженого до місця відбування покарання знає про нього практично все. На оперативному обліку перебувають всі засуджені, які мають пряме відношення до кримінальної субкультури (це в першу чергу, лідери і авторитети злочинного середовища).

Більше того, при правильному спілкуванні психолога виправної колонії з новоприбулим засудженим можна встановити, яке його відношення до кримінального середовища 3 його ідеологією, мораллю, законами та звичаями, атрибутикою і традиціями субкультури. Однак, важливо не стільки виявити лідера або авторитета злочинного середовища, як провести роз'яснювальну роботу серед вперше засуджених, які поступово можуть бути втягнуті в злочинне середовище, в тому числі, і насильницькими методами.

Не слід також забувати, що 3 моменту прибуття засудженого до виправної колонії з боку засуджених неформальних груп негативної спрямованості приділяється підвищена увага до новоприбулого, спочатку проводиться неформальне спілкування, з'ясовується його ставлення до режиму, до умов неформального життя, особливо в нічний час, іноді застосовується психологічний тиск.

I, якщо засуджений проявить інтерес до подальшої співпраці у цій групі, він може бути залучений до їі 
діяльності. Таке твердження грунтується на опитуванні оперативних працівників установ виконання покарань, які проходили перепідготовку та підвищення кваліфікації в Академії державної пенітенціарної служби.

Крім того, вищевказані респонденти вказали, що основна мета діяльності неформальних груп негативної спрямованості в місцях несвободи - це запровадження кримінальної субкультури та насильства різними засобами і способами: від поборів, утиску, отримання заборонених предметів, до створення для себе пільг або привілеїв, завоювання лідерства серед інших груп у виправній колонії, протидія адміністрації з перспективою організації застосування насильства, як до засуджених, так і персоналу місць несвободи.

Таким чином, розглядаючи взаємозв'язок кримінальної субкультури та насильства в місцях несвободи, ми дійшли висновку, що ці два явища тісно пов'язані між собою, вони негативно впливають на оперативний стан виконання і відбування засудженими покарання в установах виконання покарань, несуть у собі негативну спрямованість серед засуджених і персоналу, підривають авторитет правосуддя серед населення країни. До речі, проблеми насильства мають місце і в інших правоохоронних структурах.

Зокрема, у науковій праці «Протизаконне насильство в органах внутрішніх справ: соціологічний та історико-правовий аналіз», автори вперше розглядають не тільки феномен насильства як загальний соціокультурний феномен, проявом якого $€$ насильство в діяльності міліції як державного інституту, а і деталь- но розкривають причини, форми та види протизаконного насильства в OBC $[1$, c. 125$]$.

Варто також зазначити, що взаємозв'язок кримінальної субкультури та насильства в місцях несвободи практично $\epsilon$ в усіх пенітенціарних системах світу, але їх вияви мають різні форми.

Кримінальна субкультура та насильство серед засуджених в установах виконання покарань $\epsilon$ не тільки повсякденним атрибутом під час відбування ними покарання, а також і після їх звільнення. Більше того, кримінальною субкультурою та насильством «заражений» і персонал місць несвободи.

Вивчаючи проблему взаємозв'язку кримінальної субкультури та насильства в місцях несвободи, нами було виявлено, що серед вітчизняних та зарубіжних вчених відсутнє єдине розуміння даних явищ. Так, зарубіжний дослідник С. В. Максимов вважає, що кримінальна субкультура - це спосіб індивідуальної або правової поведінки, обумовлений неформальними нормами, правилами, ідеями, принципами, що суперечить загальній правовій культурі суспільства [2, с. 132].

I. М. Мацкевич дотримується думки, що «кримінальна субкультура - це сукупність окремо діючих субкультур злочинних груп, які виконують окремий вид кримінальної відповідальності. 3 цієї позиції доцільно говорити про злочинну субкультуру засуджених, наркоманів, повій тощо [3, с. 26].

Серед зарубіжних вчених також слід виділити теорію делінквентної субкультури, сформовану американським соціологом і кримінологом Альбертом Коєном. На його думку, 
носіями цього явища, як правило, $\epsilon$ представники нижчих соціальних прошарків населення, що фактично не мають шансів змагатися за багатство та успіх законним шляхом [4, c. 8]. До речі, концепцію А. Коєна в подальшому розвив В. Міллер, який довів, що у злочинному середовищі виникає i розвивається особлива асоціальна культура, основою якої $\epsilon$ мораль, система цінностей, норми поведінки, які не співпадають із загальноприйнятими, в якій сам злочин є морально виправданим [5, с. 7].

За визначенням вітчизняного вченого В. С. Медведєва, кримінальна субкультура - це сукупність цінностей, норм, традицій, які підміняють офіційні, загальновизнані регулятори поведінки і визначають, регламентують функціонування середовища засуджених та окремих їх представників [6, с. 124-125].

У педагогічній літературі під субкультурою взагалі вчені розуміють самостійне відносно цілісне утворення, що включає в себе ряд чітко виражених ознак: специфічний набір ціннісних орієнтацій, норм поведінки, взаємодії та взаємовідносин іiї суб'єктів; статусні структури; своєрідність уподобань, смаків та різних способів проведення дозвілля; системний набір окремих джерел постачання інформації; жаргон; фольклор тощо [7, с. 87].

Авторський колектив навчального посібника «Кримінальна субкультура: поняття, суспільна небезпека, форми та засоби впливу на правопорядок в установах виконання покарань» (О. М. Джужа, В. В. Василевич, О.Г. Колб та ін.) під кримінальною субкультурою розуміють особливу сферу життєдіяльності особи в умовах ізоляції від суспільства, яка виражається в кримінальній ідеології, специфічних етичних нормах i цінностях, естетичних установках i потребах, міфології та смаках, якими керуються засуджені у повсякденному житті та побуті [8, с. 32].

Щодо поняття «насильства», то за визначенням В. Т. Бусела, під цим терміном варто розуміти застосування фізичної сили до кого-небудь; застосування сили для досягнення чого-небудь; примусовий вплив на когось, щось [9, с. 735]. Насильство, за визначенням Всесвітньої організації охорони здоров'я, - навмисне застосування фізичної сили або влади, вчинене або у вигляді загрози, спрямованої проти себе, проти іншої особи, групи осіб або громади, результатом якого $€$ (або $\epsilon$ високий ступінь ймовірності цього) тілесні ушкодження, смерть, психологічна травма, відхилення в розвитку або різного роду шкоди [10, с. 219]. Отже, ці визначення поєднують навмисність і фактичне вчинення акту насильства, незалежно від його результату. Водночас застосування слів «використання влади» розширює традиційне розуміння природи насильницького акту тим, що включає в поняття насильства дії, джерелом яких $\epsilon$ влада над людиною, тобто загрози і залякування.

Важливо зазначити, що в Особливій частині Кримінального кодексу України поняття «насильство» вживається в більш ніж 40 статтях як кваліфікуюча ознака низки злочинів окремих видів. До насильства законодавець відносить не тільки насильницькі дії засуджених або персоналу, а й кримінальні явища, які визначаються іншими термінами, що описують дії, які характеризують «насильство» в широкому його розу- 
мінні, або «насильство» як одну 3 форм його прояву.

До речі, вивчаючи злочинність серед засуджених у місцях несвободи, вітчизнянй дослідник A. І. Богатирьов шляхом опитування персоналу виправних колоній Міністерства юстиції України встановив наявність у них кримінальних лідерів, які своїми протиправними діями, в тому числі, і насильством, суттєво впливають на основну масу засуджених, виступають посередниками регулювання конфліктних ситуацій серед засуджених на основі кримінальної субкультури.

Поряд із тим, як наголошує поіменований вчений, на жаль, Міністерство юстиції України у відкритих звітах, інформаційних бюлетенях не зазначає про наявність в установах виконання покарань кримінальних лідерів і виявів насильства серед засуджених, а тому встановити їх кількість та їх вплив на засуджених можливо лише шляхом проведення монографічних досліджень і, насамперед, опитування засуджених і персоналу місць несвободи, особливо працівників оперативних підрозділів [11, с. 180].

Варто також відмітити, що проведене опитування засуджених у місцях несвободи Інститутом кримінально-виконавчої служби на предмет субкультури показало, що 345 опитаних осіб із 607 підтвердили, що вони під час відбування покарань зустрічалися $з$ елементами субкультури (тюремна переписка, поділ людей на «касти» тощо) [12, с. 22].

Отже, ми маємо всі підстави підтримати вітчизняних вчених про те, що існування сьогодні злочинних угруповань у середовищі засуджених до покарання у виді позбавлення волі $\epsilon$ викликом кримінальному та кримінально-виконавчому законодавству й Міністерству юстиції України.

Більше того, вітчизняний дослідник С. Ю. Замула вважає, що ці угрупування формуються 3 числа осіб, які мають злочинне минуле (незалежно від того, були вони за це притягнуті до кримінальної відповідальності, чи ні), їх питома вага в цих угрупуваннях $€$ переважною [13, c. 23].

Ураховуючи ізольованість, у якій перебувають засуджені, факти застосування до них з боку кримінальних елементів психічного, фізичного та сексуального насильства в більшості випадків залишаються прихованими. Однією із причин приховування насильства вищевказаними засудженими опитані нами засуджені (80\%) вказують на побоювання повторного насильства.

До речі, за нашими дослідженням $40 \%$ робочого часу адміністрація виправних колоній середнього і максимального рівнів безпеки витрачає на врегулювання конфліктів серед засуджених. Це пов'язано з такими негативними проявами в місцях несвободи, як сплата боргу, крадіжка речей засуджених, прояви сексуального насильства, приниження тощо.

Крім того, кримінальна субкультура та насильство не тільки впливають на засуджених або персонал місць несвободи, вони також стають на перешкоді належного функціонування установ виконання покарань Міністерства юстиції України, оскільки в більшості випадків ці негативні явища орієнтовані на протидію адміністрації виправних колоній, особливо середнього і максимального рівнів безпеки та меті 
виправлення і ресоціалізації засуджених.

Таким чином, серед основних ознак взаємозв'язку кримінальної субкультури та насильства в місцях несвободи можна виділити:

- самоорганізацію засуджених на противагу бездіяльності адміністрації установи виконання покарань і окремої групи засуджених на вчинення насильства до них та виживання в суворих умовах місць несвободи;

- регулярні конфлікти в середовищі засуджених щодо розподілу сфер впливу (збут наркотиків, алкоголь, проституція, надання послуг у виді «кришування» тощо);

- поширення тюремної лірики, особливо перед новоприбулими вперше в місця несвободи (перевірка на стійкість, психологічну витримку, визначення емоційного стану тощо);

- факти здирництва (грошей, продуктів харчування, одягу тощо);

- схилення до гомосексуалізму (фізичне та психологічне приниження, пригноблення тощо).

Отже, небезпека кримінальної субкультури та насильства в місцях несвободи полягає у постійному впливі їх на свідомість засуджених, на їх соціально-психологічний стан i поведінку під час відбування покарання, на прояви насильства, що в кінцевому результаті призводять до вчинення засудженим нового злочину.

Водночас, кримінальна субкультура та насильство в місцях несвободи має специфічні особливості впливу на засуджених. Перебуваючи у специфічному середовищі, зі спільним способом життя, зі схожими долями і вчиненими суспільно небезпечними діяннями (вбивство, краді- жка, зґвалтування, розбій, тілесні ушкодження тощо) засуджені, хочуть того чи ні, активно формуються в неофіційні групи різної спрямованоcтi.

Це, на думку вітчизняних вчених Л. Ф. Гули та О. М. Гуміна, відбувається у результаті безпосередніх, доволі тривалих міжособистісних стосунків між засудженими під час спілкування у різних сферах життєдіяльності. Більше того, як зазначають дослідники, засуджені в місцях несвободи відчувають дефіцит спілкування зі звичайним для них соціальним оточенням і компенсують його, підвищуючи інтенсивність спілкування у реальному найближчому оточенні [14, с. 72].

Висновки. Отже, на підставі вищевикладеного ми доходимо висновку, що кримінальна субкультура та насильство в місцях несвободи перебувають в складному взаємозв'язку з режимом в цих місцях і своїм виявом негативно впливають на ввесь процес виконання і відбування засудженими кримінальних покарань, що викликає насильство в місцях несвободи та $є$ передумовою збільшення пенітенціарної злочинності.

Переконані, що засуджені, схильні до вчинення насильства в місцях позбавлення волі мають перебувати на профілактичному обліку установи виконання покарань, відноситися до неформальних груп негативної спрямованості, і бути в полі зору оперативних підрозділів.

Враховуючи той факт, що вперше засуджені можуть перебувати в зоні ризику застосування до них засудженими неформальних груп негативної спрямованості різних форм насильства, що виявляється в проце- 
сі взаємовідносин у самому середовищі засуджених (кримінальна каста, сексуальне насильство, психічне приниження тощо), ми рекомендуємо, адміністрації колоній в дільниці карантину, діагности і розподілу, проводити групову та індивідуальну бесіду з новоприбулими засудженими на предмет подальшої їх комунікації із засудженими неформальних груп негативної спрямованості.

\section{Список використаних джерел}

1. Протизаконне насильство в органах внутрішніх справ: соціологічний та історико-правовий аналіз / В. О. Соболєв, О. Н. Ярмиш, О. А. Мартиненко, Д. А. Кобзін, I. П. Рущенко; Нац. ун-т внутр. справ, Харк. правозахис. група, Харк. ін-т соц. дослідж. Харків : Вид-во Нац. ун-ту внутр. справ: Харк. правозах. група, 2005. 212 с.

2. Максимов С. В. Краткий криминологический словарь. Москва, 1995. 543 с. C. 25-26.

3. Мацкевич И. М. Криминальна субкультура. Российское право. 2005 . № 1.

4. Cohen A. K. The sociology of the deviant act: anomie theory and beyond. American Sociological Review. Vol. 30. № 1 (Feb., 1965). P. 5-14.

5. Cloward R. A., Ohlin L. E. Delinquency and Opportunity: A Theory of Delinquent Gangs. International Journal of Group Psychotherapy. 1960. № 11(4). P. 485.

6. Медведев В. С. Кримінальна психологія. Київ : НАВСУ, 2003. 234 с.

7. Мудрик А.В. Социальна педагогика: учеб. для вузов / под. ред. В. А. Сластенина. 3-е изд. испр. и доп. Москва, 2000. 200 с.

8. Кримінальна субкультура: поняття, суспільна небезпека, форми та засоби впливу на правопорядок в установах виконання покарань: навчальний посібник. Київ: Інститут обдарованої дитини, 2015. 146 с.

9. Великий тлумачний словник сучасної української мови (з дод., допов. та CD) / уклад. і голов. ред. В. Т. Бусел. Київ; Ірпінь: Перун, 2009. 1736 с. 364 c.

10. Дюк В. А. Компьютерная психодиагностика. Санкт-Петербург : Братство, 1994.

11. Богатирьов А. І. Антикриміногенний вплив на злочинність серед засуджених в місцях несвободи : монографія. Херсон : Видавничий дім «Гельветика», 2019. 432 c.

12. Бараш Є. Ю. Кримінологічні ознаки «професійної» злочинності (на підставі соціологічного опитування). Кримінологічна теорія і практика: досвід, проблеми сьогодення та шляхи їх вирішення : матеріали міжвузів. наук-практ. круглого столу (Київ, 22 берез. 2019 р.) / редкол : В. В. Чернєй, С. Д. Гусарєв, С. С. Чернявський та ін. Київ : Нац. акад. внутр. справ. 2019. 320 с.

13. Замула С. Ю. Профілактика впливу кримінальної субкультури на неповнолітніх засуджених у спеціальних виховних установах: навч.-метод. посіб. / за заг. ред. В. М. Оржеховської. Київ : ТОВ «Білоцерківдрук», 2011. 240 с.

14. Гула Л. Ф. Організаційно-правові заходи протидії протиправній діяльності кримінальних лідерів в установах пенітенціарної системи України: монографія / за ред. проф. В. Л. Ортинського. Львів : Видавництво Львівської політехніки. 2017. 380 с.

\section{References}

1. Illegal violence in internal affairs bodies: sociological and historical and legal analysis. (2005). National. Un-t internal. of business, Kharkov. human rights group, Kharkov. in-t of soc. research. Kharkov: Nac. un-t of internal. affairs: Kharkov. human rights group [in Ukrainian]. 
2. Maksimov, S. V. (1995). Short criminological dictionary. Moscow [in Russian].

3. Matskevich, I. M. (2005). Criminal subculture. Russian law, 1, 25-26 [in Russian].

4. Cohen, A. K. (1965). The sociology of the deviant act: anomie theory and beyond. American Sociological Review, 30 (1), 5-14.

5. Cloward, R. A., Ohlin L. E. (1960). Delinquency and Opportunity: A Theory of Delinquent Gangs. International Journal of Group Psychotherapy, 11 (4), 485.

6. Medvedev, V. S. (2003). Criminal Psychology. Kyiv: NAVDU [in Ukrainian].

7. Mudrik, A. V. (2000). Social pedagogy: stud. for universities. Moscow [in Russian].

8. Criminal subculture: concept, social danger, forms and means of influencing the rule of law in penal institutions: training manual. (2015). Kyiv: Gifted child institute [in Ukrainian].

9. Busel V. T. (Ed.). (2009). The Great Interpretative Dictionary of Modern Ukrainian Language. Kyiv; Irpen: Perun [in Ukrainian].

10. Duke, V. A. (1994). Computer psychodiagnostics. St. Petersburg: Bratstvo [in Russian].

11. Bogatyrev, A. I. (2019). Uncriminogenic influence on crime among convicts in custodial settings: monograph. Kherson: Gelvetika publishing house [in Ukrainian].

12. Barash, Ye. U. Criminological signs of «professional» crime (based on sociological survey). Criminological theory and practice: experience, problems and ways to solve them: materials of the university. sciences-practical. Round table (Kyiv, 22 mar. 2019). Kyiv: Nac. acad. of internal. affairs [in Ukrainian].

13. Zamula, S. Yu. (2011). Prevention of the Influence of Criminal Subculture on Juvenile Convicts in Special Educational Institutions. Kyiv: «Bilocerkivdruk» LLC [in Ukrainian].

14. Gula, L. F. (2017). Organizational and legal measures against illegal activities of criminal leaders in institutions of the penitentiary system of Ukraine. Lviv: Publishing house of Lviv «Polytechnic» [in Ukrainian].

O. Bohatyrova, Doctor of Law, Senior Researcher, Professor of the Department criminal law and criminology of the University of the State Fiscal Service of Ukraine

ORCID ID: 0000-0003-4630-4408

O. Mykhailyk, PhD in Law, candidate for Doctor of Law degree at Security Management, Law Enforcement and Anti-Corruption Activities Chair of Interregional Academy of Personnel Management

e-mail: dmitriyyy92@ukr.net; ORCID ID: 0000-0002-2113-4888

\section{Relationship between criminal subculture and violence in custodial settings}

The article deals with the interconnection of criminal subculture and violence in custodial settings. It is proved that the criminal subculture as a manifestation of violence in custodial settings is characterized by a special type of life of convicted persons in conditions of isolation from society, has its own criminal ideology and substantially influences forms of violence among convicts and personnel of custodial settings.

The author selected signs for detection a criminal subculture in custodial settings, such as: self-organization of convicts in opposition to the inactivity of the administration of penal institutions and a separate group of convicts for committing 
violence against them and surviving in harsh conditions of custodial settings; regular conflicts among convicts regarding the distribution of spheres of influence (drug sales, alcohol, prostitution, provision of services in the form of «freezing», etc.); the spread of prison lyrics especially for new arrivals for the first time in custodial settings (verification of resistance, psychological endurance, determination of emotional state, etc.); facts of extortion (money, food, clothing, etc.); committing violence (homosexuality, physical and psychological humiliation, oppression, etc.).

It is proved that the criminal subculture and violence in custodial settings are closely interconnected, they are arranged by a certain system of relations between convicts, manifestations of negative values, skillful cultivation of traditions and customs of the criminal environment. And therefore it is clear that criminal groups that are formed in custodial settings and adhere to certain laws and traditions, recognize their way of life.

At the same time, criminal subculture and violence in custodial settings have specific features of influence on convicts. Being in a specific environment, with a common way of life, with similar luck and committed socially dangerous acts (murder, theft, rape, robbery, bodily injuries, etc.) convicts, want or not, actively form informal groups of different orientations.

It is concluded that the criminal subculture and violence in custodial settings are in a complex interconnection with the procedure and conditions of serving punishment, and its manifestation negatively affect the entire penitentiary process.

Keywords: criminal subculture; manifestation; violence; convicted person; custodial settings. 